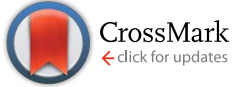

Cite this: RSC Adv., 2015, 5, 72579

Received 22nd June 2015

Accepted 12th August 2015

DOI: $10.1039 / \mathrm{c} 5 \mathrm{ra} 15852 \mathrm{~d}$

www.rsc.org/advances

\section{Coordination behaviour of new open chain and macrocyclic peptidomimetic compounds with copper(II) $\uparrow$}

\author{
Prashant D. Wadhavane, Lingaraju Gorla, Armando Ferrer, $\$$ Belén Altava, \\ M. Isabel Burguete, M. Ángeles Izquierdo and Santiago V. Luis*
}

\begin{abstract}
Two valine-derived bis(amino amides) ligands have been prepared and fully characterized. Both compounds contain additional functionalities that implement their basicity and their water solubility. Besides, compound 1 is an open chain ligand, while 2 is a macrocycle. Their protonation constants as well as their stability constants for the formation of the corresponding $\mathrm{Cu}^{2+}$ complexes have been determined potentiometrically. Important differences are associated to the macrocyclic effect and to the additional functionalities in the spacer. The presence of an additional amine group and/or the inclusion of a carboxylic side chain in this spacer increase the stabilities of the $\mathrm{Cu}^{2+}$ complexes, suggesting its participation in the interaction with the metal. Thus, 2 is the first pseudopeptidic cyclophane of this family displaying the ability to form highly stable metal complexes in water. UV-Vis and ESI-MS were used for analyzing the complex species detected in the speciation diagram.
\end{abstract}

\section{Introduction}

Enzymes are essential for biological processes. In many cases their activity is associated to the presence of metalloenzymes in which metal cofactors mediate the corresponding biological transformations. ${ }^{1}$ In particular, for enzymatic systems involving transport of electrons and dioxygen, as well as oxidation and oxygenation processes, the presence of copper is important. ${ }^{2}$ The exact properties of those active centers are often related to the coordination geometry of copper. As a diverse family of proteins, copper proteins could be divided into several types. ${ }^{1 d}$ One classical example is that of azurins, which catalytic center harbors a type 1 copper site. ${ }^{\mathbf{1 d , 3}}$ In those systems a carboxylate group, derived from the side chains of aspartate and glutamate, is present. The involvement of a carboxyl group in the coordination environment of the metal center also takes place, moreover, in binuclear enzymes like the metalloenzyme Zn-phosphorotriesterase. ${ }^{4}$

The most common geometries reported for copper complexes include octahedral, tetrahedral, ${ }^{5}$ distorted tetragonal, ${ }^{6}$ distorted trigonal pyramidal or bipyramidal, ${ }^{7}$ and square planar arrangements around the metal center. ${ }^{8}$ Copper

Departament of Inorganic and Organic Chemistry, Universitat Jaume I, Campus del Riu Sec, Av. Sos Baynat, s/n, E-12071, Castellón, Spain.E-mail: luiss@uji.es

$\dagger$ Electronic supplementary information (ESI) available: Potential protonation equilibria for 2 (S1). ${ }^{1} \mathrm{H}$ NMR spectra of compound 1 at different $\mathrm{pH}$ values (S2), Mass Spectra (S3) and computational models (S4). See DOI: 10.1039/c5ra15852d \$ Permanent address: Departamento de Química, Facultad de Ciencias Naturales, Universidad de Oriente, Avda. Patricio Lumumba s/n., 90500 Santiago de Cuba, Cuba. complexes with open-chain and macrocyclic polydentate amine ligands are frequently pentacoordinate. ${ }^{9}$ With this coordination number the complexes can adopt structures that can be described as either square pyramidal (sp) or trigonal bipyramidal (tbp) depending mainly on the actual nature of the ligand. One illustrative example is that of tripodal tetradentate ligands that favour tbp coordination. ${ }^{10}$ In this regard, the design and synthesis of ligands functionalized to achieve metal complexation in a biomimetic approach is a challenge of current interest. ${ }^{\mathbf{1 1} 12}$

Although many model complexes use non amino acid ligands mimicking various aspects of the ligand environment in proteins, the development of new ligands based on the presence of amino acid subunits is a fundamental approach in this area. ${ }^{12,13}$ In this context, amino acid derived open-chain and macrocyclic compounds have recently drawn much attention in very different fields like synthetic, ${ }^{14}$ bioorganic, ${ }^{15}$ medicinal, ${ }^{16}$ supramolecular chemistry, ${ }^{17}$ and catalysis, ${ }^{18}$ and recent contributions from our group have shown how minimalistic pseudopeptides derived from simple natural amino acids can have important applications, ${ }^{19}$ for instance in the selective recognition of carboxylic acids $^{\mathbf{2 0}}$ and amino acid derivatives, ${ }^{\mathbf{2 1}}$ and for developing new selfassembled materials ${ }^{22}$ or molecular rotors. ${ }^{21 a, 23}$

Previous studies have revealed the capacity of some $C_{2}$ symmetric open-chain pseudopeptides to form stable metal complexes in aqueous solution. ${ }^{24}$ However, the same capacity is absent in most of the related pseudopeptidic cyclophanes studied because of their higher lipophilic character, decreasing their water solubility, and the structural strain developed for the coordination of several donor atoms in the macrocycle to the 
same metal center. Taking all this into account, the design and study of macrocyclic pseudopeptides incorporating carboxylate pendant groups coexisting with amino and amide groups is an important target. In such systems, besides the inclusion of additional donor groups, the presence of the carboxylic group can provide an important contribution to the water solubility of the resulting ligand, allowing its study under aqueous conditions of biological relevance.

Here we present our results on the acid-base and coordination properties of the macrocyclic pseudopeptide 2 containing a pendant carboxylic group. The structurally related open-chain pseudopeptide 1, lacking the carboxylic functionality has also been studied for a better analysis of the effect of the carboxylic group and the macrocyclic nature present in 2 .

\section{Results and discussion}

The structure of the ligands (1-3) considered in this work is displayed in Chart 1. The synthesis of compounds $\mathbf{1}$ and 2 is

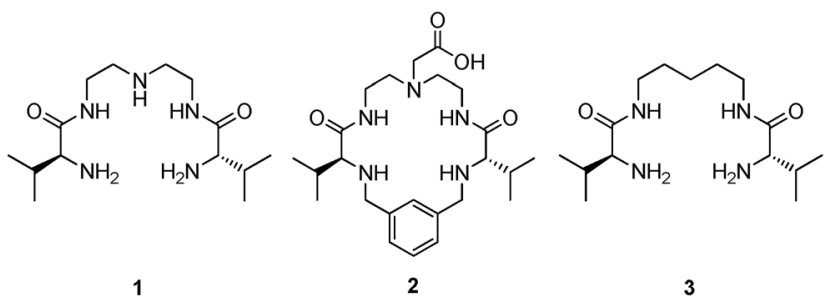

Chart 1 Bis(amino amide) ligands studied in this work. presented in Scheme 1 and follows the general synthetic approaches previously developed by us. ${ }^{25}$ The synthesis and study of the open-chain ligand 3, containing a central spacer of the same length than 1 but lacking the additional amino group has been reported elsewhere. ${ }^{24}$ The open-chain bis(amino amide) compound 1 can be easily prepared starting from $\mathrm{N}-\mathrm{Cbz}$ protected valine through the initial formation of the corresponding activated $N$-hydroxysuccinimide ester, coupling with diethylenetriamine and final $\mathrm{N}$-deprotection. The $\mathrm{N}$-Cbz protected precursor of 1 (Cbz-protected compound 6) was also a key intermediate for the synthesis of the macrocyclic compound 2 . Nevertheless this synthetic procedure is more complex as it requires a proper definition of the step at which the pendant group is introduced at the central nitrogen atom of the spacer. In this regard, we followed successfully the approach recently used for the preparation of related derivatives containing fluorescent subunits that can act as markers of acidic organelles within live cells. ${ }^{26}$ Thus, the open-chain intermediate 6 was reacted with methyl-2-bromoacetate in DMF at $50{ }^{\circ} \mathrm{C}$ for $24 \mathrm{~h}$, using $\mathrm{K}_{2} \mathrm{CO}_{3}$ as the base, to introduce the ester functionalized pendant arm. Then, deprotection of the $\mathrm{Cbz}$ group was carried out by hydrogenolysis to provide the intermediate 8 . Reaction of this compound with 1,3-bis(bromomethyl)benzene provided the macrocyclic structure 9 from which, after hydrolysis of the ester group using lithium hydroxide in a 2:1 THF-water mixture, the desired cyclic pseudopeptide 2 was obtained in $41 \%$ yield. The resulting pseudopeptide is a highly functional macrocycle with a relatively large and flexible cavity, which increases its potential for the interaction with metal cations and its water solubility.

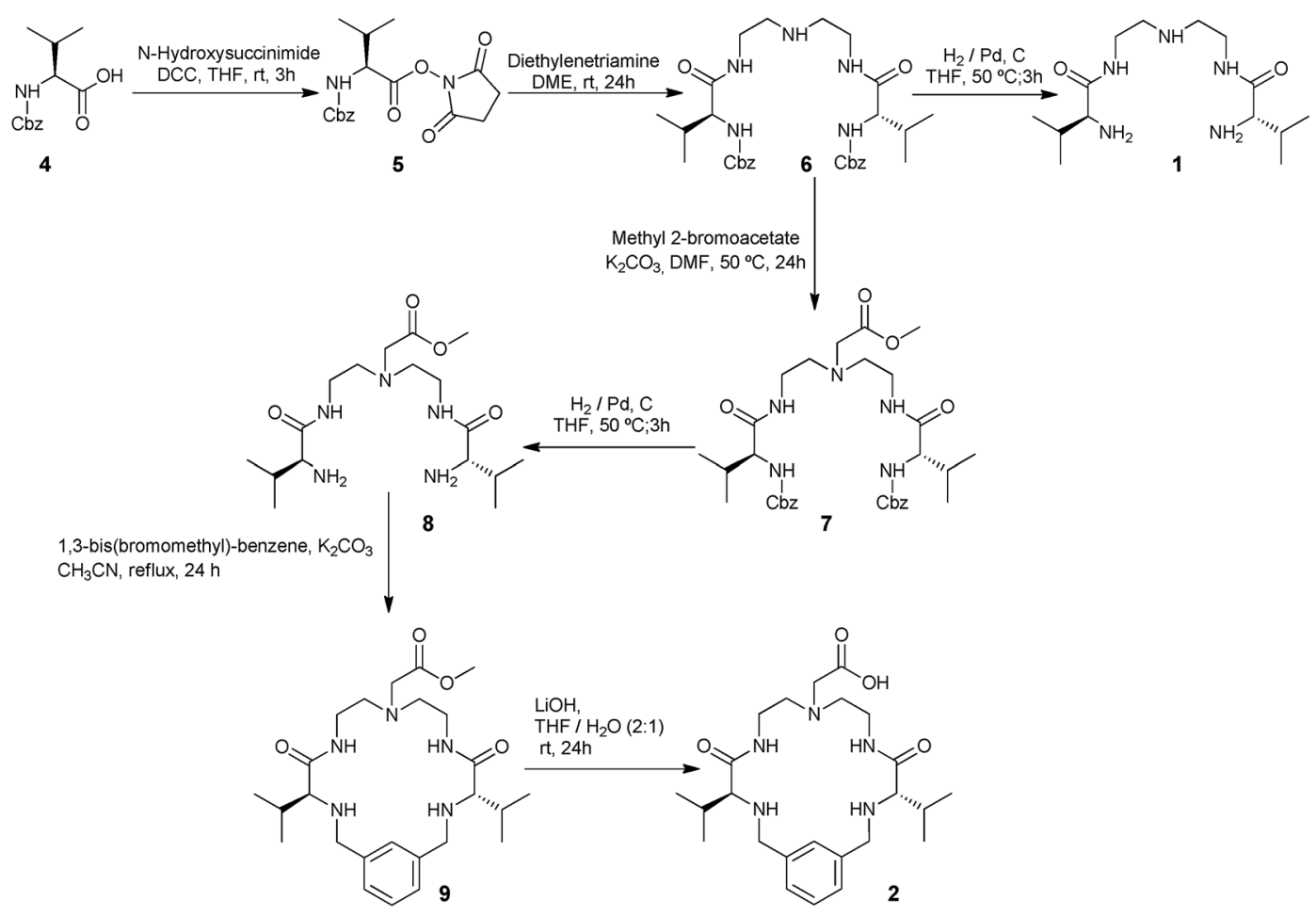

Scheme 1 Synthetic route for the preparation of the open chain (1) and macrocyclic (2) pseudopeptidic compounds. 


\section{Acid-base studies}

The presence of the additional nitrogen atom in the central spacer, in particular the tertiary one in $\mathbf{2}$, and the carboxylic group present in the pendant arm of the macrocyclic derivative 2 must significantly affect the acid-base properties of these compounds when compared to those of related systems (i.e. 3). Thus, the acid-base properties of $\mathbf{1}$ and 2 were studied using potentiometric titrations. All the titrations were carried out as is fully described in the experimental section, at $298.1 \pm 0.1 \mathrm{~K}$ using $\mathrm{NaCl} 0.1 \mathrm{M}$ to maintain a constant ionic strength. The cumulative and stepwise stability constants for the protonation of these pseudopeptidic valine derivates obtained following this methodology are presented in Table 1, along with those for the related compound 3 previously determined. ${ }^{24}$ According to their structure, three protonation constants are detected for $\mathbf{1}$ and four for 2 , while only two protonation constants are present in the related compound 3 . To facilitate the analysis of the data the monoanionic carboxylate derived from 2 has been considered as the L species (see Fig. 1). Charges have been omitted for clarity in the description of the different protonated and complex species.

Table 1 Logarithms of the stepwise protonation constants of pseudopeptidic compounds $1-3$ determined in $\mathrm{NaCl} 0.1 \mathrm{M}$ at $298.1+0.1 \mathrm{~K}$

\begin{tabular}{llll}
\hline Reaction $^{a}$ & $\mathbf{1}$ & $\mathbf{2}$ & $3^{b}$ \\
\hline $\mathrm{H}+\mathrm{L} \rightleftharpoons \mathrm{HL}$ & $9.02(1)^{c}$ & $10.01(1)$ & $8.11(4)$ \\
$\mathrm{H}+\mathrm{HL} \rightleftharpoons \mathrm{H}_{2} \mathrm{~L}$ & $7.86(1)$ & $7.95(1)$ & $7.31(4)$ \\
$\mathrm{H}+\mathrm{H}_{2} \mathrm{~L} \rightleftharpoons \mathrm{H}_{3} \mathrm{~L}$ & $6.93(1)$ & $6.45(1)$ & \\
$\mathrm{H}+\mathrm{H}_{3} \mathrm{~L} \rightleftharpoons \mathrm{H}_{4} \mathrm{~L}$ & - & $5.87(2)$ &
\end{tabular}

${ }^{a}$ Charges omitted for clarity. ${ }^{b}$ Taken from ref. 24. ${ }^{c}$ Values in parentheses are the standard deviations in the last significant figure. Values lower than 2 have not been considered. Charges omitted for clarity.
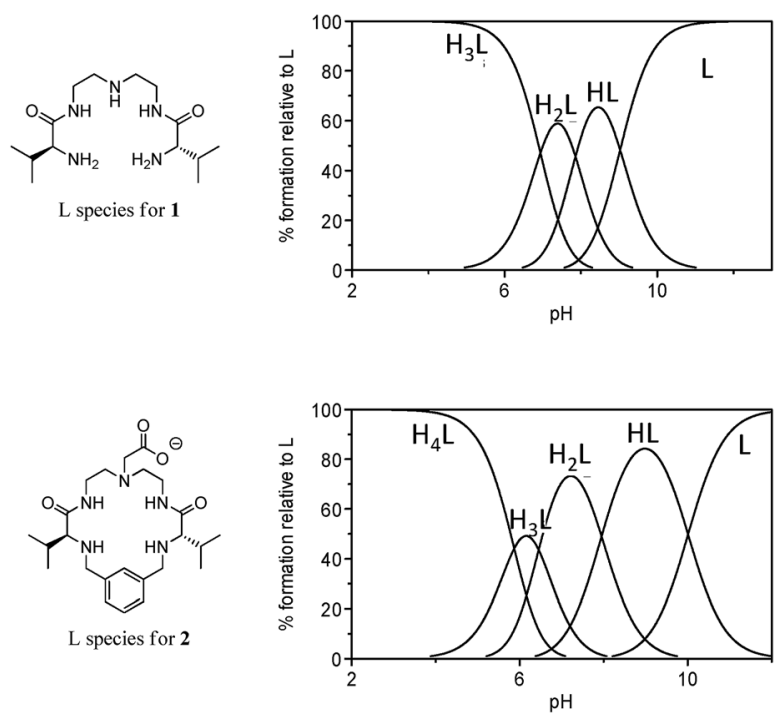

Fig. 1 Distribution diagrams for protonated species of 1 (top) and 2 (bottom) in 0.1 M NaCl at 298.1 K. Charges have been omitted for clarity.
Regarding the values of the stepwise protonation constants, data in Table 1 show that compound 2, having three basic nitrogen atoms and one basic carboxylate, displays the higher constant $(\log K=10.01)$ for the formation of the [HL] species. This first protonation can be assigned to the carboxylate group or to one of the amine groups, leading to the formation of a neutral or a zwitterionic species. In this regard, computational calculations carried out at the PM3 level revealed a strong stabilization of the zwitterionic structures for 2 relative to the neutral species. In the same way, as could be expected, this first protonation is easier for the open-chain pseudopeptide $\mathbf{1}$ with three basic nitrogen atoms than for the reference dibasic compound $3(\log K=9.02$ for 1 and 8.11 for 3$)$. However, the second and third protonation constants are relatively similar for 1 and $2\left(\log K=7.86\right.$ and 7.95 for $\left[\mathrm{H}_{2} \mathrm{~L}\right], 6.93$ and 6.45 for $\left[\mathrm{H}_{3} \mathrm{~L}\right]$, respectively). Compound 3 presents a second protonation constant that is only slightly lower that the ones obtained for $\mathbf{1}$ and 2. This seems to suggest that the $\left[\mathrm{H}_{2} \mathrm{~L}\right]$ species for $\mathbf{1}$ and 2 involves the preferential protonation at the two more distant amine nitrogen atoms to reduce the electrostatic repulsion. The higher conformational freedom of the open chain compounds and the more favourable solvation of the primary ammonium groups could partly compensate the effect in $\mathbf{2}$ of the presence of the carboxylate group. For the macrocyclic ligand a fourth constant is identified, which can be associated with its full protonation, including the acid group in the pendant arm $(\log K=5.87)$.

The resulting distribution diagrams for the protonated species of 1 and 2 are shown in Fig. 1. For the open chain ligand the diagram shows the predominance of non-protonated species (L) at $\mathrm{pH}$ values slightly higher than 9. For compound 2, the anionic species (L), corresponding to the presence of a carboxylate group and non-protonated amino groups, predominates in the very basic region $(\mathrm{pH}>10)$, while the neutral species (HL), is prevalent at the $\mathrm{pH}$ range 8-10. In general, the different positively charged species of 2 appear at slightly more acidic regions that those with the same charge in $\mathbf{1}$, in particular for the fully protonated species $\left(\mathrm{H}_{4} \mathrm{~L}\right.$ for 2 and $\mathrm{H}_{3} \mathrm{~L}$ for $\left.\mathbf{1}\right)$.

The location of the protons in the protonated species is not a simple matter, in particular for 2 , considering the presence of several basic fragments, which leads to the existence of a very complex set of potential protonation equilibria at most protonation steps (see ESI $\dagger$ for protonation equilibria). The ${ }^{1} \mathrm{H}$ NMR spectra obtained at different $\mathrm{pH}$ values in $\mathrm{D}_{2} \mathrm{O}$ are in agreement with the distribution diagrams obtained and suggest that all the different nitrogen atoms are protonated, at some extent, in the different $\left[\mathrm{H}_{x} \mathrm{~L}\right]$ species. Fig. 2 displays the ${ }^{1} \mathrm{H}$ NMR spectra, at different $\mathrm{pH}$ values, for the macrocyclic compound 2 (see $\mathrm{ESI} \dagger$ for data regarding compound 1). The coexistence of several structures for each protonated species is confirmed by the complexity of the spectra at intermediate $\mathrm{pH}$ values. Interestingly, the formation of the zwitterionic species seems to involve the protonation of one of the benzylic nitrogen atoms, as the corresponding signals ( $\mathrm{AB}$ doublets at $>3.6 \mathrm{ppm}$ ) are the ones experiencing a more significant shift when changing from $\mathrm{pH} 11.4$ to $\mathrm{pH} 8.3$, although the signal corresponding to proton $\mathrm{b}$ located in $\alpha$ relative to the tertiary amine group is also slightly 
shifted. On the other hand, the last protonation also seems to affect significantly to this position as shown by the additional changes observed at very acidic $\mathrm{pH}$ values. This is also in good agreement with the observation in fluorescent systems related to 2 that full protonation of the benzylic amine groups, required for activating the fluorescence, takes place only at the acidic regions $\left(\mathrm{p} K_{\mathrm{a}}=4.45-4.83\right)$.

\section{Determination of the $\mathrm{Cu}^{2+}$ complexes formation constants}

The interaction of $\mathrm{Cu}^{2+}$ and ligands $\mathbf{1}$ and $\mathbf{2}$ was systematically studied by potentiometric titrations in aqueous solution over the 2-11 pH range. The stability constants for the formation of $\mathrm{Cu}^{2+}$ complexes were determined in water for a $1: 1$ metalligand ratio, using $0.1 \mathrm{M} \mathrm{NaCl}$ to maintain a constant ionic strength and a temperature of $298.1 \mathrm{~K}$. The results obtained are presented in Table 2 and the corresponding distribution diagrams are displayed in Fig. 3.

The presence of an additional nitrogen donor atom in the central spacer linking the two amino acid subunits provides, as could be expected, the formation of significantly more stable complexes. This is clearly observed when comparing the values of the constants for open chain pseudopeptides 1 and 3. As shown in the table, these values are at least two orders of magnitude higher for the ligand $\mathbf{1}$. This is particularly relevant for the formation of the [CuL] species. The value of this constant for 1 is higher than that reported for ethylenediamine $(\log K=$ $10.60)^{27}$ in spite of the more favourable chelating ring that can be achieved in the case of ethylenediamine, suggesting that more than two nitrogen atoms are involved in the coordination to the metal. The existence of an additional carboxylate donor group in L for 2 provides [CuL] formation constants significantly higher for this ligand. However, if we compare the
Table 2 Logarithms of the cumulative and stepwise formation constants for the $\mathrm{Cu}^{2+}$ complexes of ligands 1-3 determined in $0.1 \mathrm{M}$ $\mathrm{NaCl}$ at $298.1 \pm 0.1 \mathrm{~K}$

\begin{tabular}{|c|c|c|c|}
\hline Reaction $^{a}$ & 1 & 2 & $3^{b}$ \\
\hline $\mathrm{Cu}+\mathrm{L} \rightleftarrows \mathrm{CuL}$ & $11.03(1)^{c}$ & $12.19(2)$ & $6.76(1)$ \\
\hline $\mathrm{Cu}+\mathrm{L}+\mathrm{H} \rightleftarrows \mathrm{CuHL}$ & $16.46(1)$ & $19.29(3)$ & $12.51(4)$ \\
\hline $\mathrm{Cu}+\mathrm{L}+2 \mathrm{H} \rightleftarrows \mathrm{CuH}_{2} \mathrm{~L}$ & - & $23.73(3)$ & - \\
\hline $\mathrm{Cu}+\mathrm{L} \rightleftarrows \mathrm{CuH}_{-1} \mathrm{~L}+\mathrm{H}$ & $3.052(2)$ & $2.44(1)$ & $-0.23(2)$ \\
\hline $\mathrm{Cu}+\mathrm{L} \rightleftarrows \mathrm{CuH}_{-2} \mathrm{~L}+2 \mathrm{H}$ & $-6.457(2)$ & $-7.05(1)$ & $-9.89(3)$ \\
\hline $\mathrm{Cu}+\mathrm{L} \rightleftarrows \mathrm{CuH}_{-3} \mathrm{~L}+3 \mathrm{H}$ & $-16.96(4)$ & - & - \\
\hline $\mathrm{CuL}+\mathrm{H} \rightleftarrows \mathrm{CuHL}$ & $5.43(1)$ & $7.10(2)$ & $5.74(3)$ \\
\hline $\mathrm{CuHL}+\mathrm{H} \rightleftarrows \mathrm{CuH}_{2} \mathrm{~L}$ & - & $4.44(3)$ & - \\
\hline $\mathrm{CuL} \rightleftarrows \mathrm{CuH}_{-1} \mathrm{~L}+\mathrm{H}$ & $-7.978(1)$ & $-9.75(1)$ & $-7.00(2)$ \\
\hline $\mathrm{CuH}_{-1} \mathrm{~L} \rightleftarrows \mathrm{CuH}_{-2} \mathrm{~L}+\mathrm{H}$ & $-9.509(1)$ & $-9.49(1)$ & $-9.66(4)$ \\
\hline $\mathrm{CuH}_{-2} \mathrm{~L} \rightleftarrows \mathrm{CuH}_{-3} \mathrm{~L}+\mathrm{H}$ & $-10.503(1)$ & - & - \\
\hline
\end{tabular}

${ }^{a}$ Charges omitted for clarity. ${ }^{b}$ Taken from ref. $24 .{ }^{c}$ Values in parentheses are the standard deviations in the last significant figure. Values lower than 2 have not been considered.

complex formation constants calculated for the neutral ligands ( $\mathrm{L}$ for $\mathbf{1}$ and HL for $\mathbf{2}$ ) the situation is different. Thus, the value of the constant for the formation of the [CuL] dicationic species for $1(\log K=11.03)$ can be compared to that for the dicharged [CuHL] species for 2 ( $\mathrm{HL}+\mathrm{Cu} \rightleftarrows \mathrm{CuHL}, \log K=9.28$ ). This seems to preclude a relevant contribution of the macrocyclic effect in this case, most likely for it is counterbalanced by the increase in structural stress associated to the presence of the rigid aromatic ring. As has been observed for other $C_{2}$ symmetric pseudopeptides like 3, ligands $\mathbf{1}$ and $\mathbf{2}$ can form stable copper complex through mono- and bisdeprotonation of the $\mathrm{N}-\mathrm{H}$ amide functional groups, which can be easily monitored through spectroscopic measurements. ${ }^{24}$ Both

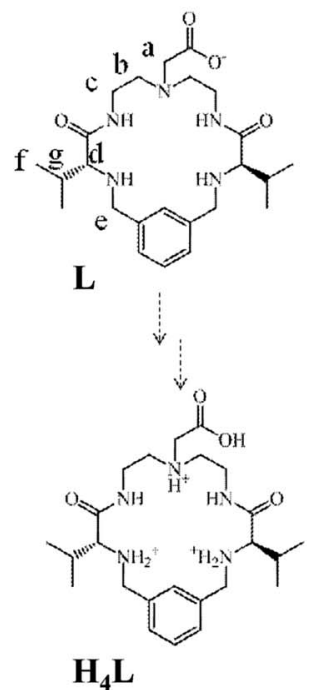

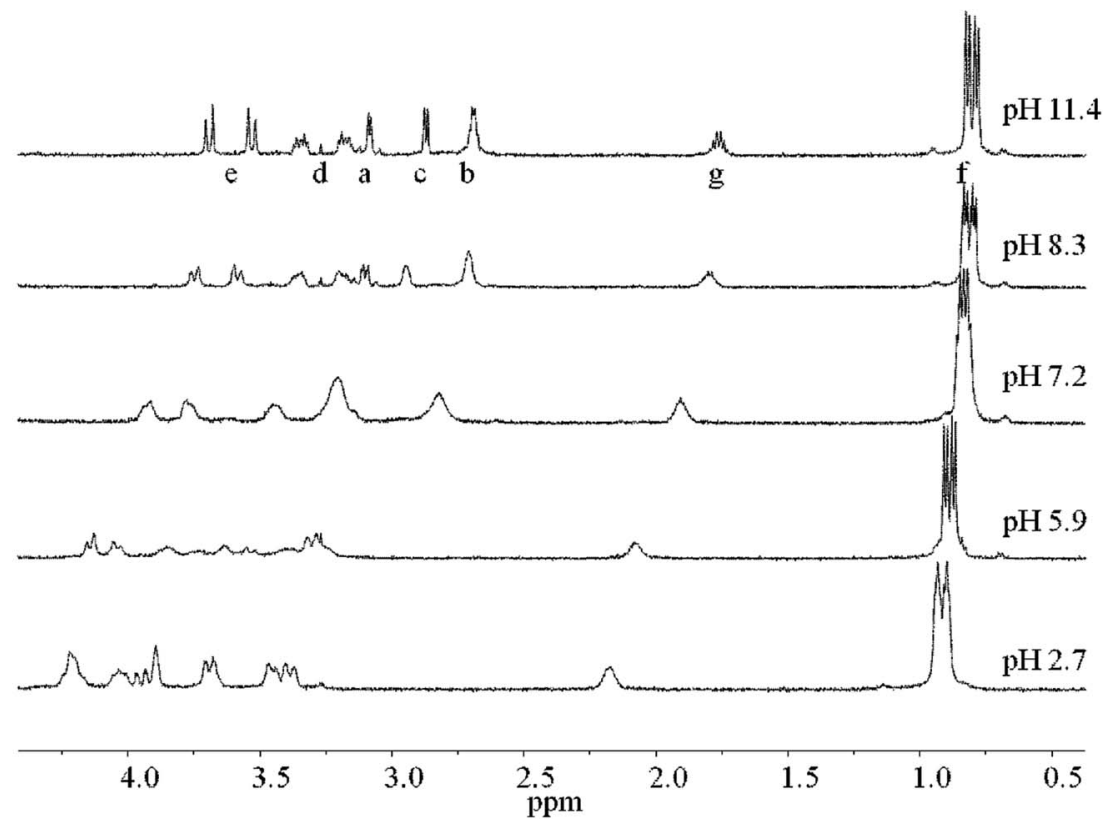

Fig. $2{ }^{1} \mathrm{H}$ NMR spectra in $\mathrm{D}_{2} \mathrm{O}$ for the different protonated species derived from compound 2 at different pH values. Major species present according to the distribution diagrams: $\mathrm{pH} 11.4(\mathrm{~L}) ; \mathrm{pH} 8.3(\mathrm{HL}) ; \mathrm{pH} 7.2\left(\mathrm{H}_{2} \mathrm{~L}\right) ; \mathrm{pH} 5.9\left(\mathrm{H}_{3} \mathrm{~L}\right) ; \mathrm{pH} 2.7\left(\mathrm{H}_{4} \mathrm{~L}\right)$. 

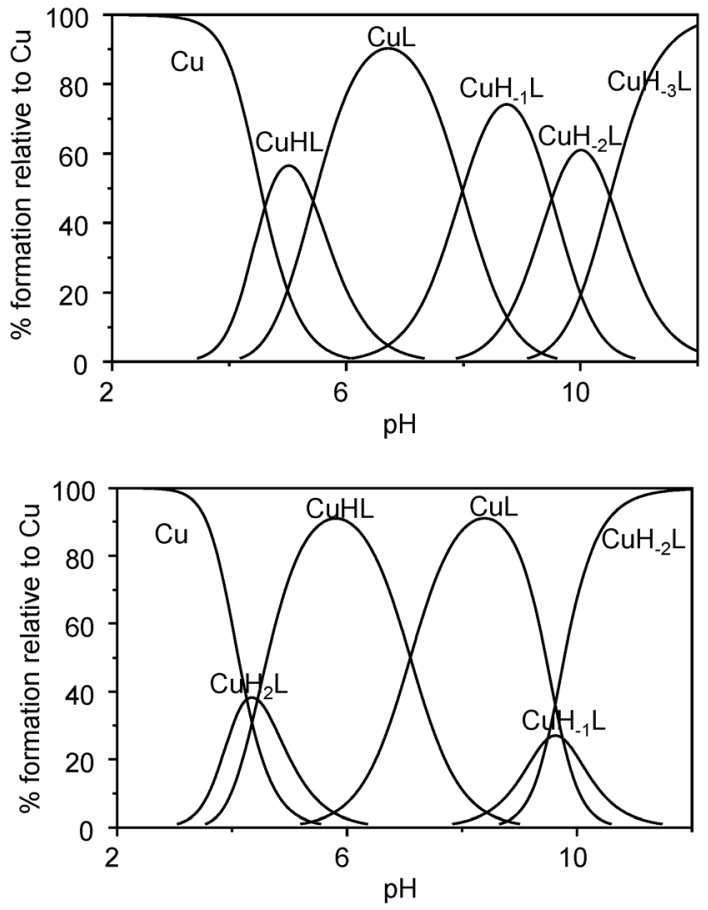

Fig. 3 Distribution diagrams for the systems $\mathrm{Cu}^{2+}-1$ (top) and $\mathrm{Cu}^{2+}-2$ (bottom) determined in $0.1 \mathrm{M} \mathrm{NaCl}$. Charges omitted for clarity.

deprotonation steps are detected and should correspond to the formation of the monocationic $\left[\mathrm{CuH}_{-1} \mathrm{~L}\right]$ and neutral $\left[\mathrm{CuH}_{-2} \mathrm{~L}\right]$ species for 1 and the neutral $\left[\mathrm{CuH}_{-1} \mathrm{~L}\right]$ and monoanionic [ $\mathrm{CuH}$ neutral $\left[\mathrm{CuH}_{-2} \mathrm{~L}\right]$ species $\left._{2} \mathrm{~L}\right]$ species for 2 . Although, formally, in the case of 2 a species like $\left[\mathrm{CuH}_{-1} \mathrm{~L}\right]$ could also correspond to the complex formed by the ligand bisdeprotonated at both amide groups and protonated at the carboxyl group, the large difference between the $\mathrm{p} K_{\mathrm{a}}$ values for both functionalities seems to preclude this possibility. The analysis of the distribution diagrams is also consistent with this situation, as this species is only present for 2 at $\mathrm{pH}$ values around 10 at which the carboxyl group should not be protonated.

It is worth mentioning that the presence of an additional nitrogen atom in the central spacer is not reflected in an increased basicity of the [CuL] complex for $\mathbf{1}$, indicating a strong participation of all the amino groups in the coordination to the metal. Thus, the constants determined for the process $\mathrm{CuL}+\mathrm{H}$ $\rightleftarrows \mathrm{CuHL}$ are $\log K=5.43$ for 1 and $\log K=5.74$ for the reference compound 3. A higher first protonation constant is detected for $2(\log K=7.10)$, but this must correspond to the protonation of the carboxylate fragment in the monocationic $[\mathrm{CuL}]$ species. As a matter of fact, a second protonation for this complex, that should correspond to the protonation of a nitrogen atom, is also detected $(\log K=4.44)$. Interestingly, in the case of $\mathbf{1}$, the formation of a monoanionic complex species, $\left[\mathrm{CuH}_{-3} \mathrm{~L}\right]$ is detected, which should correspond to the deprotonation of a coordinated water molecule to form the corresponding hydroxide. Such a complex has not been detected for 3 , revealing the important structural differences associated to the presence of the third amino group in the spacer. As this species starts to be present at $\mathrm{pH}$ values above 8 (Fig. 3), this could be of interest in the development of catalytic applications and biomimetic models, for instance as simplified HCA mimics. ${ }^{28}$ For the macrocyclic ligand 2, this is not observed as the carboxylate group can coordinate to the copper center instead of the hydroxide anion.

The distribution diagrams for 1 and 2 displayed in Fig. 3 show that species with similar total charge are predominant at each $\mathrm{pH}$ region. In both cases, the monocationic and dicationic complexes ([CuH $\left.{ }_{-1} \mathrm{~L}\right]$ and $[\mathrm{CuL}]$ for 1 and $[\mathrm{CuL}]$ and $[\mathrm{CuHL}]$ for 2 ) are the major species identified around neutral $\mathrm{pH}$ values. Overall, the macrocyclic ligand 2 represents the first example of this family of pseudopeptidic cyclophanes being able to display a significant capacity to form stable copper complexes in aqueous solutions and for a broad range of $\mathrm{pH}$ values.

The use of ESI-MS has been revealed to be of great help for the identification of supramolecular species. ${ }^{29}$ Nevertheless, it is important to realize that the nature of the species present in purely aqueous solutions can differ from those under the conditions required for ESI-MS analysis, in particular taking into account that ESI-MS experiments require the use of methanolic solutions or water-methanol mixtures. In spite of this, its potential to detect species even at very low concentrations is a unique feature of this technique. ${ }^{30}$ On the other hand, many different studies have shown how ESI-MS allows properly detecting the complex species observed in solution. The identification of metal-ligand species is of particular relevance as the exact nature of the complex can be efficiently confirmed by the analysis of the corresponding isotopic patterns. This has been used previously to confirm the metal complex species formed by ligands related to 3 , revealing that similar results are obtained in methanol and in aqueous solutions containing some methanol. ${ }^{24}$ Accordingly, the ESI technique in the positive mode of analysis was used to confirm the species observed at the different $\mathrm{pH}$ regions in the distribution diagrams for $\mathbf{1}$ and 2. Thus, for instance (Fig. 4), at basic $\mathrm{pH}$ values (pH range 9-11) a peak at 403 was clearly detectable for ligand 1 (Fig. 4). This peak can be assigned to the solvated $\left(\mathrm{H}_{2} \mathrm{O}\right)$ sodium ion adduct of the neutral species $\left[\mathrm{CuH}_{-2} \mathrm{~L}\right],\left[\mathrm{CuH}_{-2} \mathrm{~L}+\mathrm{H}_{2} \mathrm{O}+\mathrm{Na}^{+}\right]^{+}$. The base peak, however, appears at 363 corresponding to the monocationic species $\left[\mathrm{CuH}_{-2} \mathrm{~L}+\mathrm{H}\right]$ obtained from the neutral complex $\left[\mathrm{CuH}_{-2} \mathrm{~L}\right]$, or directly from the monocationic species $\left[\mathrm{CuH}_{-1} \mathrm{~L}\right]$. In addition, a peak at 385 can be assigned to $\left[\mathrm{CuH}_{-2} \mathrm{~L}\right.$ $\left.+\mathrm{Na}^{+}\right]^{+}$, whose $+\mathrm{H}_{2} \mathrm{O}$ and $+2 \mathrm{H}_{2} \mathrm{O}$ species are $\left[\mathrm{CuH}_{-2} \mathrm{~L}+\mathrm{H}_{2} \mathrm{O}+\right.$ $\left.\mathrm{Na}^{+}\right]^{+}$(403) and $\left[\mathrm{CuH}_{-2} \mathrm{~L}+\mathrm{H}_{2} \mathrm{O}+\mathrm{Na}^{+}\right]^{+}$(421), respectively. Complex species formed by the monodeprotonated or bisdeprotonated ligand predominate in solution in this $\mathrm{pH}$ region. The second most intense peak appears at 302, corresponding to the protonated free ligand $[\mathrm{HL}]$. The monoanionic $\left[\mathrm{CuH}_{-3} \mathrm{~L}\right]^{-}$ species could not be observed even with the use of the ESI in negative mode.

The $\mathrm{ESI}^{+} \mathrm{MS}$ spectra for the $\mathrm{Cu}^{+2}$ complexes with 2 at $\mathrm{pH}=$ 11.5 presents a base peak at 545 . Taking into account that $\mathrm{L}$ has been defined for 2 as monoanionic (see Fig. 1), this peak can be assigned to the monocationic $\left[\mathrm{CuH}_{-2} \mathrm{~L}+\mathrm{H}^{+}+\mathrm{Na}^{+}\right]^{+}$species, while the peak at 561 should correspond to the monocationic $\left[\mathrm{CuH}_{-2} \mathrm{~L}+\mathrm{H}^{+}+\mathrm{K}^{+}\right]^{+}$species (see ESI $\dagger$ ), again in good agreement with the distribution diagram. 


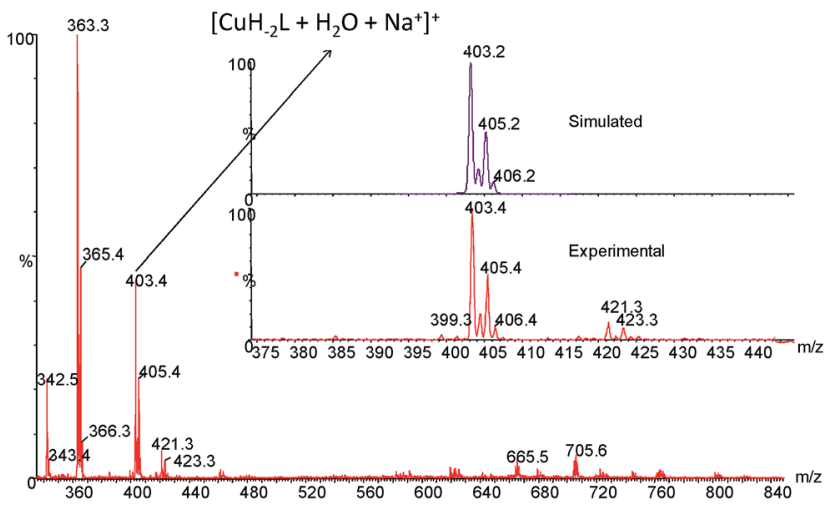

Fig. $4 \mathrm{ESI}^{+}-\mathrm{MS}$ spectra for $\mathrm{Cu}^{2+}$ complexes with 1 at $\mathrm{pH}=11.0$ in methanol.

Spectroscopic analyses also provided additional information on the exact nature of the complex species. As for other ligands related to 3 , FT-IR spectra of the $\mathrm{Cu}^{2+}$ complexes formed by $\mathbf{1}$ and 2 under basic condition revealed the participation of deprotonated amide groups, with the observation of the corresponding amide bands at $c a .1670 \mathrm{~cm}^{-1} .{ }^{31}$ Taking advantage of the distribution diagrams presented in Fig. 3, a UV-visible spectroscopic study was carried out, by selecting preferentially those $\mathrm{pH}$ regions at which one of the complex species is dominant. A selection of the UV-visible spectra, obtained for $\mathbf{1}$ and $\mathbf{2}$ at different $\mathrm{pH}$ values are gathered in Fig. 5. The spectral window selected is the region corresponding to the $\mathrm{d}-\mathrm{d}$ transitions, which provides useful information on the coordination geometries of the respective copper complexes. ${ }^{9 h, 32}$ The respective observed values of $\lambda_{\max }$ are presented in Table 3. Interestingly, the observed $\mathrm{pH}$ dependence patterns of the molecular spectra for $\mathbf{1}$ and $\mathbf{2}$ are very similar and clearly differ from those reported for tetradentate ligands related to 3 and having different central aliphatic spacers and amino acids side chains. ${ }^{24}$ In the case of compounds related to $\mathbf{3}$, significant differences are observed in the electronic spectra with changes in the $\mathrm{pH}$ that were associated to the presence/absence of deprotonated complexes $\left[\mathrm{CuH}_{-x} \mathrm{~L}\right]^{(2-x)+}$. For regions involving the uncomplexed cation or complexes with the fully protonated ligands absorption maxima were observed in the 640-690 range, characteristic for octahedral copper complexes. On the contrary, for regions involving the predominant formation of complexes with deprotonated ligands, the maxima appear at the 490-560 range, corresponding to square planar to square-pyramidal geometries. In the case of ligands $\mathbf{1}$ and 2, however, no significant shifts in the maxima are observed for most of the $\mathrm{pH}$ values studied, although the intensity of the bands is variable. Only at very acidic $\mathrm{pH}$ values, where the uncomplexed $\mathrm{Cu}^{2+}$ cation is the major species in solution, the appearance of a new diffuse band at much larger wavelengths and a strong decrease of the original band, accompanied by a shift in its maximum, are detected. In the case of $\mathbf{1}$, the observed maxima range from 545 to $549 \mathrm{~nm}$, except for the more acidic region, while for 2 the maxima of the spectra, for the same $\mathrm{pH}$ range, appear at $579-590 \mathrm{~nm}$.
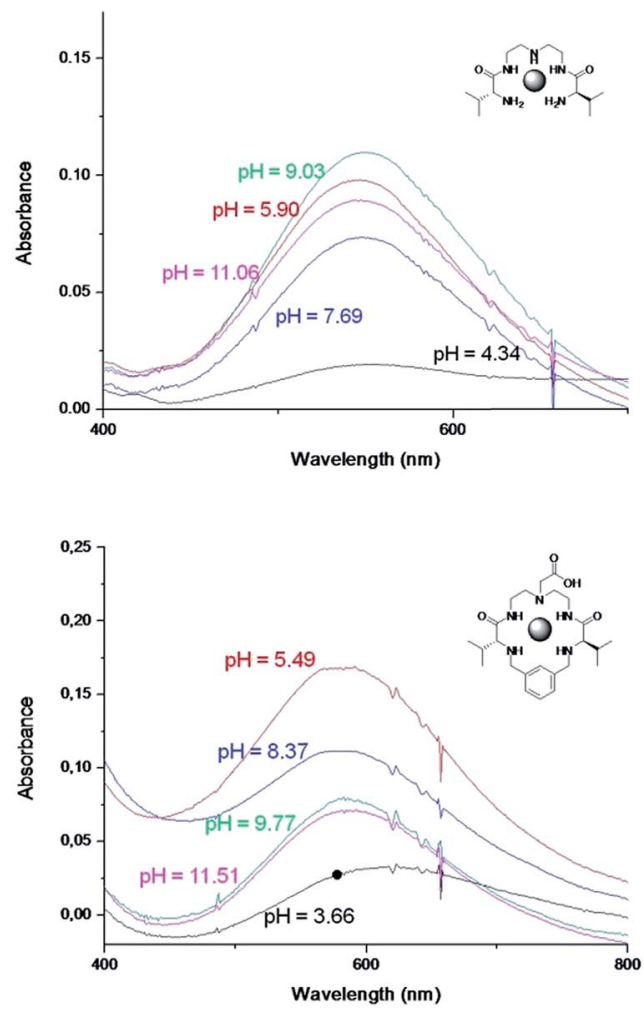

Fig. 5 UV-visible spectra obtained for 1: 1 Cu : L mixtures for ligands 1 (top) and 2 (bottom) at different $\mathrm{pH}$ values.

Table 3 Observed values of $\lambda_{\max }$ for the UV-visible spectra of $\mathrm{Cu}$ complexes with 1 and 2 at different $\mathrm{pH}$ values

\begin{tabular}{|c|c|c|c|}
\hline $\mathrm{L}$ & $\mathrm{pH}$ & $\lambda_{\max }(\mathrm{nm})$ & $\begin{array}{l}\text { Major species from distribution diagrams } \\
\text { (abundance in \%) }\end{array}$ \\
\hline \multirow[t]{5}{*}{1} & 4.3 & 555 & $\mathrm{Cu}(45), \mathrm{CuHL}(45), \mathrm{CuL}(10)$ \\
\hline & 5.9 & 545 & CuL (70), CuHL (30), \\
\hline & 7.7 & 546 & $\mathrm{CuL}(60) \mathrm{CuH}_{-1} \mathrm{~L}(40)$ \\
\hline & 9.0 & 549 & $\mathrm{CuH}_{-1} \mathrm{~L}(70), \mathrm{CuH}_{-2} \mathrm{~L}(10), \mathrm{CuL}(10)$ \\
\hline & 11.0 & 547 & $\mathrm{CuH}_{-3} \mathrm{~L}(90)$ \\
\hline \multirow[t]{5}{*}{2} & 3.7 & 624 & $\mathrm{Cu}(40), \mathrm{CuH}_{2} \mathrm{~L}(40), \mathrm{CuHL}(20)$ \\
\hline & 5.5 & 590 & CuHL (90) \\
\hline & 8.4 & 579 & $\operatorname{CuL}(90)$ \\
\hline & 9.8 & 583 & $\mathrm{CuH}_{-1} \mathrm{~L}(30), \mathrm{CuH}_{-2} \mathrm{~L}(30), \mathrm{CuL}(30)$ \\
\hline & 11.5 & 585 & $\mathrm{CuH}_{-2} \mathrm{~L}(95)$ \\
\hline
\end{tabular}

This should be in good agreement with the maintenance, for the different complex species formed, of a predominant square planar to square-pyramidal geometry $(500-600 \mathrm{~nm}) \cdot{ }^{9 h}$ This last geometry is common to many complexes formed by pentadentate ligands, ${ }^{33}$ and many five-coordinate copper(II) complexes adopt square pyramidal arrangements of the donor atoms around the metal center, in some cases with a clear distortion towards a trigonal pyramidal coordination..$^{34}$ For $\mathbf{1}$, the square planar base can be easily formed by the two amides and two amine groups from the amino acid moieties, while the additional nitrogen atom or, in basic media, a hydroxide anion could occupy the apical position. 
A similar situation can be expected for the complexes formed by ligand 2 , although in this case we need to take into account the steric constrains imposed by the macrocyclic structure and the presence of the carboxyl/carboxylate group that could act as an additional donor group in the coordination to copper(II). This can lead to distorted square pyramidal complexes or distorted square planar complexes. In some cases, the transition from square pyramidal to trigonal bipyramidal has been observed to be associated to a bathochromic shift from around 550 to $c a .600 \mathrm{~nm}$, as is observed here..$^{33}$

Computational models (MMFF) reveal, in good agreement with experimental data, that distorted square planar and square pyramidal geometries can be easily achieved, for instance, for complexes of both deprotonated ligands (see ESI $\dagger$ ). They suggest, taking also into consideration former studies with related systems, that a square planar arrangement can be achieved involving the two deprotonated amide groups and two amine nitrogen atoms. The additional coordination to the third amino group, to the carboxylate in 2 or to a water molecule could transform this square planar arrangement into square pyramidal. However, the existence of different possible structural possibilities for those arrangements and the low energy differences calculated for many of them does not allow an unambiguous definition of the coordination geometries in the absence of additional data, in particular crystal structures. Thus, different complex structures could coexist, for instance, for the $\left[\mathrm{CuH}_{-2} \mathrm{~L}\right]$ species predominant at the basic region. The same can apply for [CuL] and the related protonated complex species for which an efficient coordination to the metal seems to take place and can involve the amino groups and the carbonyl oxygen atoms of the amide groups. Similar results are obtained in the case of the ligand $\mathbf{1}$ (see ESI†).

\section{Conclusions}

The introduction of a nitrogen atom in the central spacer linking the two amino acid subunits in $C_{2}$ symmetric pseudopeptides provides important changes in the properties of the resulting derivatives (i.e. 1 and 2) relative to those of the parent compounds like 3 . The presence of this additional nitrogen atom increases the basicity of the resulting system and the number of donor atoms for coordination to metal ions like $\mathrm{Cu}(\mathrm{II})$, but besides, facilitates the building of more elaborated structures as is illustrated in the case of 2 . Overall, this modification significantly increases their solubility in water and affords pentadentate ligands that are able to form more stable $\mathrm{Cu}(\mathrm{II})$ complexes than the parent ligand 3. Copper complex species dominate the distribution diagram for $\mathrm{pH}$ values above 5. The geometry of these complexes, having different protonation states, seems to be very similar, most likely from square planar to square-pyramidal, a behaviour clearly divergent from the one found for ligand 3 and related compounds. The existence of a large enough flexible cavity in the case of the macrocyclic compound $\mathbf{2}$ and the presence of the six potential donor groups in the macrocyclic structure allows the formation of strong metal complexes for this ligand, in spite of the important steric constraints often found for structures of this class like polyaza $[n]$ cyclophanes. ${ }^{35}$ Thus, the macrocyclic ligand 2 represents the first example of this family of receptors with a significant capacity to form stable copper complexes in aqueous solutions and for a broad range of $\mathrm{pH}$ value.

\section{Experimental section}

\section{Materials and reagents}

All reagents were obtained from commercial sources and used as received unless otherwise stated. Dimethoxyethane (DME) was dried and distilled from molecular sieves $(4 \AA)$ and then stored over molecular sieves. Deionised water was used from a Milli-Q water system by Millipore.

\section{Synthesis and characterization of organic compounds}

Synthesis of 5. To a clear solution of $N$-Cbz-L-valine 4 (25 g, $99.49 \mathrm{mmol}$ ) and $N$-hydroxysuccinimide (11.45 g, $99.49 \mathrm{mmol}$ ) at $0{ }^{\circ} \mathrm{C}$ was added DCC $(20.52 \mathrm{~g}, 99.49 \mathrm{mmol})$ in anhydrous THF in a dropwise manner, and the reaction mixture was stirred at $0-5{ }^{\circ} \mathrm{C}$ for $3 \mathrm{~h}$. The dicyclohexylurea formed was filtered off and the filtrate was concentrated to dryness. The crude product was recrystallized from 2-propanol to obtain the pure product. Yield 87\% (49 g); m.p. $119-120^{\circ} \mathrm{C} ;[\alpha]_{\mathrm{D}}^{25}=-20.1^{\circ}\left(c=0.1, \mathrm{CHCl}_{3}\right)$; IR $(\mathrm{KBr}) 3360,1741,1526 \mathrm{~cm}^{-1} ;{ }^{1} \mathrm{H}$ NMR $\left(300 \mathrm{MHz}, \mathrm{CDCl}_{3}\right)(\delta$, ppm): 1.02 (d, 6H, $J=7.4 \mathrm{~Hz}), 1.06$ (d, 6H, $=7.7 \mathrm{~Hz}), 2.31(\mathrm{~m}$, $1 \mathrm{H}), 2.77(\mathrm{~s}, 4 \mathrm{H}), 4.66(\mathrm{dd}, 1 \mathrm{H}, J=4.7 \mathrm{~Hz}), 5.13(\mathrm{~s}, 2 \mathrm{H}), 5.43$ (d, $1 \mathrm{H}, J=9.5 \mathrm{~Hz}), 7.28-7.41(\mathrm{~m}, 5 \mathrm{H}) ;{ }^{13} \mathrm{C} \mathrm{NMR}\left(75 \mathrm{MHz}, \mathrm{CDCl}_{3}\right):(\delta$, ppm): 17.2, 18.7, 25.5, 31.5, 57.4, 67.2 , 128.0, 128.1, 128.3, 135.8, 155.6, 167.5, 168.6; anal. calcd (\%) for $\mathrm{C}_{17} \mathrm{H}_{20} \mathrm{~N}_{2} \mathrm{O}_{6}: \mathrm{C}, 58.6 ; \mathrm{H}$, 5.8; N, 7.7; found: C, 58.1; H, 5.9; N, 8.0.

Synthesis of 6. To a clear solution of the $N$-hydroxysuccinimide ester of $N$-Cbz-L-valine $5(30.0 \mathrm{~g}, 86.12 \mathrm{mmol})$ in anhydrous dimethoxyethane (DME, $250 \mathrm{~mL}$ ) at $0{ }^{\circ} \mathrm{C}$, diethylenetriamine $(4.46 \mathrm{~g}, 43.06 \mathrm{mmol})$ dissolved in dry DME (20 $\mathrm{mL}$ ) was added in a dropwise manner. The reaction mixture was stirred at room temperature for $18 \mathrm{~h}$ and then was heated to 40$50{ }^{\circ} \mathrm{C}$ for $6 \mathrm{~h}$. The white solid formed was filtered and washed with cold water and cold methanol. Yield 94\% (23.27 g), m.p. = $175^{\circ} \mathrm{C} ;[\alpha]_{\mathrm{D}}^{25}=11.39^{\circ}\left(c=0.1, \mathrm{CHCl}_{3}\right)$; IR (ATR) 3285, 2957, $1685,1649,1535,1236 \mathrm{~cm}^{-1} ;{ }^{1} \mathrm{H}$ NMR $\left(500 \mathrm{MHz}, \mathrm{DMSO}-d_{6}\right)(\delta$, ppm): 7.83 (s, 2H), 7.38-7.23 (m, 8H), $7.19(\mathrm{~d}, 2 \mathrm{H}, J=8.3 \mathrm{~Hz})$, 5.07-4.94 (m, 4H), 3.83-3.68 (m, 4H), 3.10 (dd, $4 \mathrm{H}, J=12.6,6.1$ $\mathrm{Hz}), 1.98-1.84(\mathrm{~m}, 2 \mathrm{H}), 0.82(\mathrm{~d}, 12 \mathrm{H}, J=6.1 \mathrm{~Hz}) .{ }^{13} \mathrm{C} \mathrm{NMR}(75$ MHz, DMSO- $\left.d_{6}\right)(\delta, \mathrm{ppm}): 174.7,171.8,156.8,137.8,129.0$, 128.4, 128.3, 66.1, 61.1, 48.9, 30.9, 19.9, 18.9; HRMS (ESI-TOF) ${ }^{+}$ Calcd for $\mathrm{C}_{30} \mathrm{H}_{43} \mathrm{~N}_{5} \mathrm{O}_{6}\left(\mathrm{M}+\mathrm{H}^{+}\right)$570.3292. Found $570.3296(\mathrm{M}+$ $\mathrm{H}^{+}$); anal. calcd for $\mathrm{C}_{30} \mathrm{H}_{43} \mathrm{~N}_{5} \mathrm{O}_{6} \mathrm{H}_{2} \mathrm{O}: \mathrm{C}, 61.3, \mathrm{H}, 7.7, \mathrm{~N}, 11.9$. Found. C, 61.4, H, 7.8, N, 11.9.

Synthesis of 7. A mixture of compound 6 (10 g, $17.55 \mathrm{mmol})$, anhydrous $\mathrm{K}_{2} \mathrm{CO}_{3}(24.25 \mathrm{~g}, 175.5 \mathrm{mmol})$ and methyl bromoacetate $(2.68 \mathrm{~g}, 19.30 \mathrm{mmol})$ was placed in a flask containing dry dimethylformamide (DMF, $10 \mathrm{~mL}$ ) and heated to $50{ }^{\circ} \mathrm{C}$ for $24 \mathrm{~h}$ under nitrogen atmosphere. The reaction was monitored by TLC. After complete consumption of the starting material, distilled water was added $(30 \mathrm{~mL})$. This solution was extracted by using ethyl acetate (EtOAc, $30 \mathrm{~mL}, \times 3$ ). The organic phase 
was dried over anhydrous $\mathrm{MgSO}_{4}$ and evaporated under vacuum. The product was purified by silica flash chromatography using $\mathrm{MeOH} / \mathrm{CH}_{2} \mathrm{Cl}_{2}(1: 50)$ to give the white solid 7 (8.19 g, 75\% yield): m.p. $156-158^{\circ} \mathrm{C} ;[\alpha]_{\mathrm{D}}^{25}=-10.45^{\circ}\left(c 0.1,55 \mathrm{CHCl}_{3}\right)$; IR (ATR) 3300, 3064, 3031, 2949, 2869, 2360, 1736, 1685, 1644, $1532 \mathrm{~cm}^{-1}$; ${ }^{1} \mathrm{H}$ NMR $\left(500 \mathrm{MHz}, \mathrm{DMSO}-d_{6}\right)(\delta, \mathrm{ppm}): 7.77(\mathrm{~s}, 2 \mathrm{H})$, $7.39-7.24(\mathrm{~m}, 10 \mathrm{H}), 7.17(\mathrm{~d}, 2 \mathrm{H}, J=8.8 \mathrm{~Hz}), 5.00(\mathrm{~m}, 4 \mathrm{H}), 3.78(\mathrm{t}$, $2 \mathrm{H}, J=7.9 \mathrm{~Hz}), 3.58(\mathrm{~s}, 3 \mathrm{H}), 3.37(\mathrm{~d}, 2 \mathrm{H}), 3.10(\mathrm{~m}, 4 \mathrm{H}), 2.63(\mathrm{~m}$, $4 \mathrm{H}), 1.91(\mathrm{~m}, 4 \mathrm{H}), 0.82(\mathrm{~m}, 12 \mathrm{H}) ;{ }^{13} \mathrm{C}$ NMR (126 MHz, DMSO- $\left.d_{6}\right)$ $(\delta, \mathrm{ppm}): 173.7,171.5,139.8,129.3,128.6,127.5,67.5,55.7,55.0$, 53.6, 51.5, 37.5, 31.2, 19.5, 18.0; HRMS (ESI-TOF) ${ }^{+}(\mathrm{m} / \mathrm{z})$ Calcd for $\mathrm{C}_{33} \mathrm{H}_{47} \mathrm{~N}_{5} \mathrm{O}_{8}\left(\mathrm{M}+\mathrm{H}^{+}\right)$642.3503, found 642.3508. Anal. calcd (\%) for $\mathrm{C}_{33} \mathrm{H}_{47} \mathrm{~N}_{5} \mathrm{O}_{8}$ : C, 61.8, H, 7.4, N, 10.9; found: C, 61.7, $\mathrm{H}$, 7.5, N, 10.9.

Synthesis of 8. To a clear solution of compound 7 (2.00 g, $3.11 \mathrm{mmol}$ ) in dry tetrahydrofuran (THF), $10 \mathrm{~mol} \%$ of the catalyst ( $5 \mathrm{wt} \% \mathrm{Pd}$ on activated carbon) was added. The reaction mixture was stirred under an $\mathrm{H}_{2}$ atmosphere $\left(\mathrm{H}_{2}\right.$ balloon $)$ at $50{ }^{\circ} \mathrm{C}$ for $4 \mathrm{~h}$. The reaction was monitored by TLC, and after complete consumption of the starting material the catalyst was filtered off through a Celite ${ }^{\circledR}$ bed and washed with THF. The crude product was purified by column chromatography using $\mathrm{MeOH} / \mathrm{CH}_{2} \mathrm{Cl}_{2} / \mathrm{NH}_{3}$ (1: $\left.15: 0.01\right)$ as eluent. Evaporation of the solvent under vacuum yielded the green oil $8(0.462 \mathrm{~g}, 80 \%$ yield): $[\alpha]_{\mathrm{D}}^{25}=6.26^{\circ}\left(c 0.1, \mathrm{CHCl}_{3}\right.$ ); IR (ATR) 3289, 3073, 2963, 2869, 1736, 1640, $1526 \mathrm{~cm}^{-1} ;{ }^{1} \mathrm{H}$ NMR (500 $\left.\mathrm{MHz}, \mathrm{CDCl}_{3}\right)(\delta$, ppm): 7.50 (s, 2H), $3.26(\mathrm{~m}, 4 \mathrm{H}), 3.09(\mathrm{~m}, 2 \mathrm{H}), 2.66(\mathrm{~m}, 4 \mathrm{H}), 2.10$ $(\mathrm{m}, 2 \mathrm{H}), 1.59(\mathrm{~m}, 5 \mathrm{H}), 0.87(\mathrm{~d}, 6 \mathrm{H}, J=6.8 \mathrm{~Hz}), 0.74(\mathrm{~d}, 6 \mathrm{H}, J=6.8$ $\mathrm{Hz}) ;{ }^{13} \mathrm{C} \mathrm{NMR}\left(75 \mathrm{MHz}, \mathrm{CDCl}_{3}\right.$ ) ( $\left.\delta, \mathrm{ppm}\right): 174.3,171.8,68.2,54.8$, 54.1, 51.0, 43.4 36.9, 31.2 19.6, 17.9, 15.2; HRMS (ESI-TOF) ${ }^{+}(\mathrm{m} /$ z) Calcd for $\mathrm{C}_{17} \mathrm{H}_{35} \mathrm{~N}_{5} \mathrm{O}_{4}\left(\mathrm{M}+\mathrm{H}^{+}\right)$374.2767, found 374.2762. Anal. calcd (\%) for $\mathrm{C}_{17} \mathrm{H}_{35} \mathrm{~N}_{5} \mathrm{O}_{4}$ : C, 49.9, H, 9.6, N, 17.1; found: C, 49.9, H, 9.7, N, 17.0.

Synthesis of 9. A mixture of compound 8 ( $0.50 \mathrm{~g}, 1.33 \mathrm{mmol})$, anhydrous $\mathrm{K}_{2} \mathrm{CO}_{3} \quad(1.85 \mathrm{~g}, 13.38 \mathrm{mmol})$ and 9,10bis(bromomethyl)-benzene $(0.39 \mathrm{~g}, 1.47 \mathrm{mmol})$ in dry $\mathrm{CH}_{3} \mathrm{CN}$ $(175 \mathrm{~mL})$ was stirred to reflux for $24 \mathrm{~h}$ under a nitrogen atmosphere. The reaction was monitored by TLC. After complete consumption of the starting material, the reaction mixture was filtered and the solvent was evaporated under vacuum. The crude product was purified by silica flash chromatography using $\mathrm{MeOH} / \mathrm{CH}_{2} \mathrm{Cl}_{2}(1: 25)$ as the eluent to yield the yellowish solid compound 9. Yield 72\% (0.459 g), m.p. $106{ }^{\circ} \mathrm{C},[\alpha]_{\mathrm{D}}^{25}=$ $-24.36\left(c=0.1, \mathrm{CHCl}_{3}\right.$ ); IR (ATR) 3323, 2947, 2922, 2856, 1741, 1651, 1592, $1198 \mathrm{~cm}^{-1},{ }^{1} \mathrm{H}$ NMR (500 MHz, $\left.\mathrm{CDCl}_{3}\right)(\delta, \mathrm{ppm})$ : $7.68(\mathrm{~s}, 2 \mathrm{H}), 7.38(\mathrm{~s}, 1 \mathrm{H}), 7.26-7.07(\mathrm{~m}, 5 \mathrm{H}), 3.65$ (dd, $4 \mathrm{H}, J=$ $30.0,12.1 \mathrm{~Hz}), 3.53(\mathrm{~s}, 3 \mathrm{H}), 3.42(\mathrm{~d}, 2 \mathrm{H}, J=40.9 \mathrm{~Hz}), 3.30(\mathrm{~s}, 2 \mathrm{H})$, $3.19(\mathrm{~s}, 2 \mathrm{H}), 2.85(\mathrm{~d}, 2 \mathrm{H}, J=3.4 \mathrm{~Hz}), 2.73(\mathrm{dd}, 4 \mathrm{H}, J=41.5,34.7$ $\mathrm{Hz}), 2.06(\mathrm{~d}, 2 \mathrm{H}, J=5.3 \mathrm{~Hz}), 0.82(\mathrm{dt}, 12 \mathrm{H}, J=62.3,31.1 \mathrm{~Hz}) ;{ }^{13} \mathrm{C}$ NMR (126 MHz, $\mathrm{CDCl}_{3}$ ) ( $\left.\delta, \mathrm{ppm}\right): 174.2,171.9,140.1,129.3$, 128.5, 127.6, 67.8, 55.6, 53.6, 51.5, 37.4, 31.3, 19.5, 18.0. HRMS (ESI-TOF) $^{+}$Calcd for $\mathrm{C}_{25} \mathrm{H}_{41} \mathrm{~N}_{5} \mathrm{O}_{4}\left(\mathrm{M}+\mathrm{H}^{+}\right)$476.3237. Found $476.3235\left(\mathrm{M}+\mathrm{H}^{+}\right)$. Anal. calcd (\%) for $\mathrm{C}_{25} \mathrm{H}_{41} \mathrm{~N}_{5} \mathrm{O}_{4}$ : C, 63.7, $\mathrm{H}$, 8.7, N, 14.7; found. C, 63.5, H, 8.8, N, 14.7.

Synthesis of 2 . To a clear solution of $9(0.2 \mathrm{~g}, 0.42 \mathrm{mmol})$ in 7 $\mathrm{mL}$ of $\mathrm{THF} / \mathrm{H}_{2} \mathrm{O}(2: 1)$, was added $\mathrm{LiOH}(0.07 \mathrm{~g}, 2.94 \mathrm{mmol})$ and the reaction was stirred at room temperature for $24 \mathrm{~h}(2: 1,3$
$\mathrm{mL}$ ). The reaction was monitored by using TLC; after complete consumption of the starting material, the reaction mixture was acidified ( $\mathrm{pH}$ ) by addition of $1: 1 \mathrm{HBr} / \mathrm{H}_{2} \mathrm{O}$. To this solution was added washed DOWEX® ion exchange resin $(4 \mathrm{~g})$, and the mixture was left for $18 \mathrm{~h}$ at room temperature. (The standard procedure to wash the DOWEX® ion exchange resin was as follows: $50 \mathrm{~mL}$ deionized $\mathrm{H}_{2} \mathrm{O}, 50 \mathrm{~mL} \mathrm{MeOH}, 50 \mathrm{~mL} \mathrm{H}_{2} 0,50 \mathrm{~mL}$ THF, $50 \mathrm{~mL} \mathrm{H}_{2} \mathrm{O}, 50 \mathrm{~mL} 10 \% \mathrm{NH}_{3}$ in $\mathrm{H}_{2} \mathrm{O}, \mathrm{H}_{2} \mathrm{O}$ till neutral $\mathrm{pH}, 50$ $\mathrm{mL} 2 \mathrm{M} \mathrm{HCl}, \mathrm{H}_{2} \mathrm{O}$ till neutral $\mathrm{pH}$ ). The solvent of this mixture was evaporated under vacuum, and the resulting solid was put in a column containing $20 \mathrm{~g}$ washed DOWEX ${ }^{\circledR}$ ion exchange resin and deionized $\mathrm{H}_{2} \mathrm{O}$. The eluents used for the resin column purification were: $100 \mathrm{~mL} \mathrm{H} \mathrm{H}_{2} \mathrm{O} ; 1$ : $1 \mathrm{THF} / \mathrm{H}_{2} \mathrm{O} 100 \mathrm{~mL} ; 5 \% \mathrm{NH}_{3}$ in $\mathrm{H}_{2} \mathrm{O}$. From this resin column purification the compound was isolated by the elution with $5 \% \mathrm{NH}_{3}$ in $\mathrm{H}_{2} \mathrm{O}$. Then the water was evaporated under vacuum to yield the off-white solid 2 . Yield $41 \%$ (0.80 g), m.p. $83{ }^{\circ} \mathrm{C},[\alpha]_{\mathrm{D}}^{25}=-31.84^{\circ}\left(c=0.1, \mathrm{CHCl}_{3}\right)$, IR (ATR) $3285,2957,1685,1649,1535 \mathrm{~cm}^{-1} ;{ }^{1} \mathrm{H}$ NMR $\left(500 \mathrm{MHz}, \mathrm{D}_{2} \mathrm{O}\right)(\delta$, ppm): 7.46-7.27 (m, 3H), 7.14 (s, 1H), 3.83 (d, $2 \mathrm{H}, J=12.9 \mathrm{~Hz}$ ), $3.68(\mathrm{~d}, 2 \mathrm{H}, J=13.0 \mathrm{~Hz}), 3.44-3.31$ (m, $2 \mathrm{H}), 3.19(\mathrm{dd}, 2 \mathrm{H}, J=18.6$, $8.9 \mathrm{~Hz}$ ), 3.13 (d, $2 \mathrm{H}, J=19.2 \mathrm{~Hz}), 3.07$ (d, $2 \mathrm{H}, J=5.9 \mathrm{~Hz}), 2.74$ (d, $4 \mathrm{H}, J=4.8 \mathrm{~Hz}), 1.85(\mathrm{dt}, 2 \mathrm{H}, J=11.2,5.6 \mathrm{~Hz}), 0.83(\mathrm{dd}, 12 \mathrm{H}, J=$ 14.6, $6.8 \mathrm{~Hz}) .{ }^{13} \mathrm{C} \mathrm{NMR}\left(126 \mathrm{MHz}, \mathrm{D}_{2} \mathrm{O}\right)(\delta, \mathrm{ppm}): 178.3,173.7$, 136.1, 131.1, 129.7, 128.8, 71.5, 65.8, 57.3, 53.9, 50.9, 37.1, 31.0, 18.4, 17.8. HRMS (ESI-TOF) ${ }^{+}$Calcd for $\mathrm{C}_{24} \mathrm{H}_{39} \mathrm{~N}_{5} \mathrm{O}_{4}\left(\mathrm{M}+\mathrm{H}^{+}\right)$ 462.3080. Found $462.3082\left(\mathrm{M}+\mathrm{H}^{+}\right)$. Anal. calcd (\%) for $\mathrm{C}_{24} \mathrm{H}_{39^{-}}$ $\mathrm{N}_{5} \mathrm{O}_{4} \cdot \mathrm{H}_{2} \mathrm{O}: \mathrm{C}, 60.1, \mathrm{H}, 8.6, \mathrm{~N}, 14.6$; found. C, 60.0, H, 8.6, N, 14.9 .

Synthesis of 1. To a clear solution of compound 6 (10.0 g, $17.55 \mathrm{mmol}$ ) in dry tetrahydrofuran (THF), $10 \mathrm{~mol} \%$ of the catalyst (5 wt\% Pd on activated carbon) was added. The reaction mixture was stirred under an atmosphere of $\mathrm{H}_{2}\left(\mathrm{H}_{2}\right.$ balloon) at $50{ }^{\circ} \mathrm{C}$ for $4 \mathrm{~h}$. The reaction was monitored by TLC, and after complete consumption of the starting material the catalyst was filtered off through a Celite ${ }^{\circledR}$ bed and washed with THF. The crude product was purified by column chromatography using $\mathrm{MeOH} / \mathrm{CH}_{2} \mathrm{Cl}_{2}(1: 15: 0.01)$ as eluent. Evaporation of the solvent under vacuum yielded the white solid 1. Yield $88 \%$ (4.69 g). ${ }^{1} \mathrm{H}$ NMR (300 MHz, $\left.\mathrm{CDCl}_{3}\right)(\delta, \mathrm{ppm}): 7.50(\mathrm{~s}, 2 \mathrm{H}), 3.34(\mathrm{~d}, 4 \mathrm{H}$, $J=5.7 \mathrm{~Hz}), 3.20$ (d, $2 \mathrm{H}, J=3.6 \mathrm{~Hz}), 2.76(\mathrm{t}, 4 \mathrm{H}, J=5.7 \mathrm{~Hz}), 2.30-$ $2.19(\mathrm{~m}, 2 \mathrm{H}), 1.52(\mathrm{~s}, 3 \mathrm{H}), 0.96(\mathrm{~d}, 6 \mathrm{H}, J=6.9 \mathrm{~Hz}), 0.82(\mathrm{~d}, 6 \mathrm{H}, J=$ $6.8 \mathrm{~Hz}) .{ }^{13} \mathrm{C}$ NMR $\left(75 \mathrm{MHz}, \mathrm{CDCl}_{3}\right)(\delta, \mathrm{ppm}): 174.7,77.5,77.0$, 76.6, 60.4, 48.7, 38.8, 31.0, 19.7, 16.2; ESI-MS $m / z=302.2(\mathrm{M}+$ $\mathrm{H}^{+}$). Anal. calcd (\%) for $\mathrm{C}_{14} \mathrm{H}_{31} \mathrm{~N}_{5} \mathrm{O}_{2}$ : C, 55.8, H, 10.4, N, 23.3; found. C, 56.0, H, 10.5, N, 23.5.

Electromotive force measurements. The potentiometric titrations were carried out at $298.1 \pm 0.1 \mathrm{~K}$ using $\mathrm{NaCl} 0.1 \mathrm{M}$ as supporting electrolyte. The experimental procedure (burette, potentiometer, cell, stirrer, microcomputer, etc.) has been fully described elsewhere. ${ }^{36}$ The acquisition of the emf data was performed with the computer program Crison Capture. The reference electrode was an $\mathrm{Ag} / \mathrm{AgCl}$ electrode in saturated $\mathrm{KCl}$ solution. The glass electrode was calibrated as a hydrogen-ion concentration probe by titration of previously standardized amounts of $\mathrm{HCl}$ with $\mathrm{CO}_{2}$-free $\mathrm{NaOH}$ solutions and the equivalent point determined by the Gran's method, which gives the standard potential, $E^{\circ \prime}$, and the ionic product of water $\left[\mathrm{p} K_{\mathrm{w}}=\right.$ 13.78(1)]. The computer program HYPERQUAD was used to 
calculate the protonation and stability constants, ${ }^{37}$ and the HySS program was used to obtain the distribution diagrams. ${ }^{38}$ The $\mathrm{pH}$ range investigated was $2.0-12.0$ and the concentration of the metal ions and of the ligands ranged from $1 \times 10^{-3}$ to $5 \times$ $10^{-3} \mathrm{M}$ with $\mathrm{Cu}^{2+}: \mathrm{L}$ molar ratios as $1: 1$. The different titration curves for each system (at least two) were treated either as a single set or as separated curves without significant variations in the values of the stability constants. Finally, the sets of data were merged together and treated simultaneously to give the final stability constants.

NMR measurements. The ${ }^{1} \mathrm{H}$ spectra were recorded on a Varian INOVA 500 spectrometer (500 and $125 \mathrm{MHz}$ for ${ }^{1} \mathrm{H}$ and ${ }^{13} \mathrm{C}$ NMR, respectively). The solvent signal was used as a reference standard. Adjustments to the desired $\mathrm{pH}$ were made using drops of $\mathrm{DCl}$ or NaOD solutions. The $\mathrm{pD}$ was calculated from the measured $\mathrm{pH}$ values using the correlation, $\mathrm{pH}=\mathrm{pD}-0.4 .^{39}$

Mass spectrometry. Mass spectra were recorded on a hybrid QTOF I (quadrupole-hexapole-TOF) mass spectrometer with an orthogonal Z-spray-electrospray interface (Micromass, Manchester, UK) either by electrospray positive mode (ES+) or by electrospray negative mode (ES-). The desolvation gas as well as nebulizing gas was nitrogen at a flow of $700 \mathrm{~L} \mathrm{~h}^{-1}$ and $20 \mathrm{~L}$ $\mathrm{h}^{-1}$ respectively. The temperature of the source block was set to $120{ }^{\circ} \mathrm{C}$ and the desolvation temperature to $150{ }^{\circ} \mathrm{C}$. A capillary voltage of 3.5 and $3.3 \mathrm{KV}$ was used in the positive and negative scan mode, respectively. The cone voltage was typically set to 20 $\mathrm{V}$ to control the extent of fragmentation of the identified ions. Sample solutions were infused via syringe pump directly connected to the ESI source at a flow rate of $10 \mathrm{~mL} \mathrm{~min}{ }^{-1}$. The observed isotopic pattern of each intermediate perfectly matched the theoretical isotopic pattern calculated from their elemental composition using the MassLynx 4.0 program. ${ }^{40}$

UV spectroscopy. UV-Vis absorption spectra were recorded in $\mathrm{MeOH}$, in a Hewlett-Packard 8453 apparatus, using solutions $(1 \times$ $10^{-3} \mathrm{M}$ ) at different $\mathrm{pH}$ values containing $1: 1$ ligand to metal molar ratios. Additional experiments were carried in $\mathrm{NaCl} 0.1 \mathrm{M}$ solutions. Only minimal differences were observed in this case.

IR spectroscopy. FTIR spectra were acquired on a JASCO 6200 instrument with a MIRacle single-reflection ATR diamond/ ZnSe accessory. The raw IR spectral data were processed with the JASCO spectral manager software. Solutions $\left(2 \times 10^{-3} \mathrm{M}\right)$ at different $\mathrm{pH}$ values containing $1: 1$ ligand to metal molar ratios were used for those experiments.

\section{Acknowledgements}

Financial support from the Spanish MINECO (CTQ2012-38543C03-01), Generalitat Valenciana (PROMETEO/2012/020) and PPI-UJI (P1-1B-2013-38) is gratefully acknowledged. P. D. W. and L. G. thank GV for a Santiago Grisolía fellowship. The authors are grateful to the SCIC of the Universitat Jaume I for the spectroscopic facilities.

\section{Notes and references}

1 (a) Y. Lu, N. Yeung, N. Sieracki and N. M. Marshall, Nature, 2009, 460, 855; (b) N. Mitic, S. J. Smith, A. Neves,
L. W. Guddat, L. R. Gahan and G. Shenk, Chem. Rev., 2006, 106, 3338; (c) M. L. Zastrow and V. L. Pecoraro, Coord. Chem. Rev., 2013, 257, 2565; (d) J. Liu, S. Chakraborty, P. Hosseinzadeh, Y. Yu, S. Tian, I. Petrik, A. Bhagi and Y. Lu, Chem. Rev., 2014, 114, 4366.

2 (a) R. H. Holm, P. Kennepohl and I. Solomon, Chem. Rev., 1996, 96, 2239; (b) N. Kitajima and Y. Morooka, Chem. Rev., 1994, 94, 737; (c) E. A. Lewis and W. B. Tolman, Chem. Rev., 2004, 104, 1047; (d) J. Reedijk and E. Bouwman, Bioinorganic Catalysis, MarcelDekker, New York, 2nd edn, 1999; (e) K. D. Karlin, D.-H. Lee, V. Obias and K. J. Humphreys, Pure Appl. Chem., 1998, 70, 855; (f) E. I. Solomon, F. Tuczek, D. E. Root and C. A. Brown, Chem. Rev., 1994, 94, 827; $(g)$ L. M. Mirica, X. Ottenwaelder and T. D. P. Stack, Chem. Rev., 2004, 104, 1013; (h) L. Q. Hatcher and K. D. Karlin, Adv. Inorg. Chem., 2006, 58, 131; (i) W. Kaim and B. Schwederski, Bioanorganische Chemie, 3 Aufl, B. G. Teuber, Stuttgart, Germany, 2004; (j) P. Haack and C. Limberg, Angew. Chem., Int. Ed., 2014, 53, 4282.

3 (a) F. E. Dodd, J. van Beeumen, R. R. Eady and S. S. Hasnain, J. Mol. Biol., 1998, 282, 369; (b) K. Paraskevopoulos, M. Sundararajan, R. Surendran, M. A. Hough, R. R. Eady, I. H. Hillier and S. S. Hasnain, Dalton Trans., 2006, 3067; (c) A. C. Merkle and N. Lehnert, Dalton Trans., 2012, 3355.

4 (a) J. L. Vanhooke, M. M. Benning, F. M. Raushel and H. M. Holden, Biochemistry, 1996, 35, 6020; (b) M. M. Benning, H. Shim, F. M. Raushel and H. M. Holden, Biochemistry, 2001, 40, 2712.

5 (a) N. Kitajima, K. Fujisawa and Y. Morooka, J. Am. Chem. Soc., 1990, 112, 3210; (b) R. C. Elder and M. C. Hill, Inorg. Chem., 1979, 18, 729.

6 (a) P. Comba, T. W. Hambley, M. A. Hitchman and H. Stratemeier, Inorg. Chem., 1995, 34, 3903; (b) B. J. Hathaway, J. Chem. Soc., Dalton Trans., 1972, 1196; (c) B. J. Hathaway and D. E. Billing, Coord. Chem. Rev., 1970, 5, 143; (d) M. Kalanithi, M. Rajarajan, P. Tharmaraj and S. Johnson Raja, Med. Chem. Res., 2015, 24, 1578.

7 (a) P. Comba, A. M. Sargeson, L. M. Engelhardt, J. M. Harrowfield, A. H. White, E. Horn and M. R. Snow, Inorg. Chem., 1985, 24, 2325; (b) P. V. Bernhardt, R. Bramley, L. M. Engelhardt, J. M. Harrowfield, D. C. R. Hockless, B. R. Korybut- Daszkiewicz, E. R. Krausz, T. Morgan and A. M. Sargeson, Inorg. Chem., 1995, 34, 3589; (c) P. Comba, C. Haaf and H. Wadepohl, Inorg. Chem., 2009, 48, 6604; (d) I. Castillo, A. C. Neira, E. Nordlander and E. Zeglio, Inorg. Chim. Acta, 2014, 422, 152; (e) A. Kaur, T. G. Ribelli, K. Schröder, K. Matyjaszewski and T. Pintauer, Inorg. Chem., 2015, 54, 1474.

8 (a) E. V. Rybak-Akimova, A. Y. Nazarenko, L. Chen, P. W. Krieger, A. M. Herrera, V. V. Tarasov and P. D. Robinson, Inorg. Chim. Acta, 2001, 324, 1; (b) J. P. Schneider and J. W. Kelly, J. Am. Chem. Soc., 1995, 117, 2533; (c) R. Kannappan, S. Tanase, I. Mutikainen, U. Turpeinen and J. Reedijk, Inorg. Chim. Acta, 2005, 358, 383; (d) M. R. Bryant, A. D. Burrows, C. M. Fitchett, 
C. S. Hawes, S. O. Hunter, L. L. Keenan, D. J. Kelly, P. E. Kruger, M. F. Mahonb and C. Richardson, Dalton Trans., 2015, 9269.

9 (a) S. R. Batten, B. F. Hoskins, B. Moubaraki, K. S. Murray and R. Robson, Chem. Commun., 2000, 1095; (b) T. Osako, K. D. Karlin and S. Itoh, Inorg. Chem., 2005, 44, 410; (c) M. Meyer, L. Fremond, E. Espinosa, R. Guilard, Z. P. Ou and K. M. Kadish, Inorg. Chem., 2004, 43, 5572; (d) K. Miyoshi, H. Tanaka, E. Kimura, S. Tsuboyama, S. Murata, H. Shimizu and K. Ishizu, Inorg. Chim. Acta, 1983, 78, 23; (e) R. M. Nunes, R. Delgado, M. F. Cabral, J. Costa, P. Brandao, V. Felix and B. J. Goodfellow, Dalton Trans., 2007, 4536; (f) H. Nagao, N. Komeda, M. Mukaida, M. Suzuki and K. Tanaka, Inorg. Chem., 1996, 35, 6809; $(g)$ E. J. Laskowski, D. M. Duggan and D. N. Hendrickson, Inorg. Chem., 1975, 14, 2449; (h) A. Algarra, M. G. Basallote, C. E. Castillo, M. Paz, A. Ferrer, E. García-España, J. M. Llinares, M. A. Máñez and C. Soriano, Inorg. Chem., 2009, 48, 902; (i) C. E. Castillo, A. G. Algarra, M. Á. Máñez, C. Duboc and M. G. Basallote, Eur. J. Inorg. Chem., 2012, 2514; (j) L. Acosta-Rueda, E. Delgado-Pinar, J. PitarchJarque, A. Rodríguez, S. Blasco, J. González, M. G. Basallote and E. García-España, Dalton Trans., 2015, 8255; $(k)$ J. Pitarch-Jarque, R. Belda, F. Lloret, J. Ferrando-Soria, P. Navarro, A. Lopera and E. García-España, Dalton Trans., 2015, 3378.

10 A. G. Blackman, Polyhedron, 2005, 24, 1.

11 (a) J.-M. Lehn, Angew. Chem., Int. Ed., 1988, 27, 89; (b) K. D. Karlin, Science, 1993, 261, 701; (c) R. M. Roat-Malone, Bioinorganic Chemistry: A Short Course, John Wiley \& Sons, Inc., Hoboken, NJ, 2nd edn, 2007; (d) I. Bertini, I. H. B. Gray, E. I. Stiefel and J. S. Valentine, Biological Inorganic Chemistry, Structure and Reactivity, University Science Books, Sausalito, CA, 2007; (e) R. Gramage-Doria, D. Armspach and D. Matt, Coord. Chem. Rev., 2013, 257, 776; $(f)$ O. Bistri and O. Reinaud, Org. Biomol. Chem., 2015, 13, 2849.

12 (a) H. Miyake and Y. Kojima, Coord. Chem. Rev., 1996, 148, 301; (b) C. Bazzicalupi, A. Bianchi, E. García-España and E. Delgado-Pinar, Inorg. Chim. Acta, 2014, 417, 3.

13 (a) F. Fache, E. Schulz, M. L. Tommasino and M. Lemaire, Chem. Rev., 2000, 100, 2159; (b) M. Hechavarría-Fonseca and B. König, Adv. Synth. Catal., 2003, 345, 1173; (c) J.-C. Kizirian, Chem. Rev., 2008, 108, 140; (d) J. S. Prell, T. G. Flick, J. Oomens, G. Berden and E. R. Williams, J. Phys. Chem. A, 2010, 114, 854; (e) S. K. Burke, Y. Xu and D. W. Margerum, Inorg. Chem., 2003, 42, 5807; $(f)$ B. J. Green, T. M. Tesfai and D. W. Margerum, Inorg. Chem., 2004, 43, 1463; (g) B. J. Green, T. M. Tesfai and D. W. Margerum, Dalton Trans., 2004, 3508; (h) T. M. Tesfai, B. J. Green and D. W. Margerum, Inorg. Chem., 2004, 43, 6726; (i) V. N. Dokorou, C. J. Milios, A. C. Tsipis, M. Haukka, P. G. Weidler, A. K. Powella and G. E. Kostakis, Dalton Trans., 2012, 12501; (j) C. R. Dennis, J. C. Swarts and D. W. Margerum, Reac. Kinet. Mech. Cat., 2012, 107, 27; (k) J. Dong, Y. Wang, Q. Xiang, X. Lv, W. Weng and Q. Zeng, Adv. Synth. Catal., 2013, 355, 692.
14 (a) S. E. Gibson and C. Lecci, Angew. Chem., Int. Ed., 2006, 45, 1364; (b) J. F. Billing and U. J. Nilsson, J. Org. Chem., 2005, 70, 4847; (c) S. Punna, J. Kuzelka, Q. Wang and M. G. Finn, Angew. Chem., Int. Ed., 2005, 44, 2215; (d) P. P. Cristau, M.-T. Martin, M.-E. Tran Hu Dau, J.-P. Vors and J. Zhu, Org. Lett., 2004, 6, 3183; (e) J. E. Redman, K. M. Wilcoxen and M. R. Ghadiri, J. Comb. Chem., 2003, 5, 33; $(f)$ E. Locardi, M. Stöckle, S. Garner and H. Kessler, J. Am. Chem. Soc., 2001, 123, 8189; $(g)$ C. J. White and A. K. Yudin, Nat. Chem., 2011, 3, 509; (h) S. E. Gibson and C. Lecci, Angew. Chem., Int. Ed., 2006, 45, 1364; (i) B. Lewandowski, G. De Bo, J. W. Ward, M. Papmeyer, S. Kuschel, M. J. Aldegunde, P. M. E. Gramlich, D. Heckmann, S. M. Goldup, D. M. D'Souza, A. E. Fernandes and D. A. Leigh, Science, 2013, 339, 189.

15 (a) S. Fernández-López, H.-S. Kim, E. C. Choi, M. Delgado, J. R. Granja, A. Khasanov, K. Kraehenbuehl, G. Long, D. A. Weinberger, K. M. Wilcoxen and M. R. Ghadiri, Nature, 2001, 412, 452; (b) S. Kubik, Chem. Soc. Rev., 2009, 38, 585; (c) A. V. Gulevich, L. S. Koroleva, O. V. Morozova, V. N. Bakhvalova, V. N. Silnikov and V. G. Nenajdenko, J. Org. Chem., 2011, 7, 1135; (d) K. Klemm, M. R. Stojkovic, G. Horvat, V. Tomisic, I. Piantanida and C. Schmuck, Chem.-Eur. J., 2012, 18, 1352; (e) W.-C. Lin, Y.-P. Tseng, C.-Y. Lin and Y.-P. Ye, Org. Biomol. Chem., 2011, 9, 5547.

16 (a) W. A. Loughlin, J. D. A. Tyndall, M. P. Glenn and D. P. Fairlie, Chem. Rev., 2004, 104, 6085; (b) R. C. Reid, L. K. Pattenden, J. D. A. Tyndall, J. L. Martin, T. Walsh and D. P. Fairlie, J. Med. Chem., 2004, 47, 1641; (c) R. C. Reid, G. Abbenante, S. M. Taylor and D. P. Fairlie, J. Org. Chem., 2003, 68, 4464; (d) X. Hu, K. T. Nguyen, C. L. M. J. Verlinde, W. G. J. Hol and D. Pei, J. Med. Chem., 2003, 46, 3771; (e) P. T. Lansbury and H. A. Lashuel, Nature, 2006, 443, 774; (f) G. A. Silva, C. Czeisler, K. L. Niece., E. Beniash, D. A. Harrington, J. A. Kessler and S. I. Stupp, Science, 2004, 303, 1352.

17 (a) For some examples on related systems: K. Choi and A. D. Hamilton, Coord. Chem. Rev., 2003, 240, 101; (b) K. Choi and A. D. Hamilton, J. Am. Chem. Soc., 2003, 125, 10241; (c) K. Choi and A. D. Hamilton, J. Am. Chem. Soc., 2001, 123, 2456; (d) L. Somogyi, G. Haberhauer and J. Rebek, Tetrahedron, 2001, 57, 1699; (e) M. M. Conn and J. Rebek, Chem. Rev., 1997, 97, 1647; (f) R. J. Brea, C. Reiriz and J. R. Granja, Chem. Soc. Rev., 2010, 39, 1448; $(g)$ Y.-D. Wu and S. Gellman, Acc. Chem. Res., 2008, 41, 1231; (h) J. S. Nowick, Acc. Chem. Res., 2008, 41, 1319; (i) D. Ke, C. Zhan, A. D. Q Li and J. Yao, Angew. Chem., Int. Ed., 2011, 50, 3715; (j) M. Suzuki and K. Hanabusa, Chem. Soc. Rev., 2009, 38, 967; (k) D. Das, S. Maiti, S. Brahmachari and P. K. Das, Soft Matter, 2011, 7, 7291.

18 (a) A. Arbaoui, C. Redshaw, N. M. Sanchez-Ballester, M. R. J. Elsegood and D. L. Hughes, Inorg. Chim. Acta, 2011, 365, 96; (b) M. Merschky and C. Schmuck, Org. Biomol. Chem., 2009, 7, 4895; (c) L. Weselinki, E. Szyk and J. Jurczak, Tetrahedron Lett., 2011, 52, 381; (d) J. Paradowska, M. Pasternak, B. Gut, B. Gryzzo and J. Mlynarski, J. Org. Chem., 2012, 77, 173; (e) F. Adrian, 
M. I. Burguete, J. M. Fraile, J. I. García, E. García-España, S. V. Luis, J. A. Mayoral and A. J. Royo, Eur. J. Inorg. Chem., 1999, 2347.

19 S. V. Luis and I. Alfonso, Acc. Chem. Res., 2014, 47, 112.

20 (a) F. Galindo, J. Becerril, M. I. Burguete, S. V. Luis and L. Vigara, Tetrahedron Lett., 2004, 45, 1659; (b) B. Altava, M. I. Burguete, N. Carbó, J. Escorihuela and S. V. Luis, Tetrahedron: Asymmetry, 2010, 21, 982.

21 (a) I. Alfonso, M. I. Burguete, F. Galindo, S. V. Luis and L. Vigara, J. Org. Chem., 2009, 74, 6130; (b) S. V. Luis, F. Galindo, M. I. Burguete and L. Vigara, J. Photochem. Photobiol., A, 2010, 209, 61; (c) B. Altava, M. I. Burguete, N. Carbó, S. V. Luis, V. Martí and C. Vicent, Tetrahedron Lett., 2013, 54, 72; (d) V. Martí-Centelles, M. A. Izquierdo, M. I. Burguete, F. Galindo and S. V. Luis, Chem.-Eur. J., 2014, 20, 7465; (e) E. Faggi, A. Moure, M. Bolte, C. Vicent, S. V. Luis and I. Alfonso, J. Org. Chem., 2014, 79, 4590.

22 (a) J. Becerril, B. Escuder, R. Gavara, S. V. Luis and J. F. Miravet, Eur. J. Org. Chem., 2005, 481; (b) I. Alfonso, M. Bru, M. I. Burguete, E. García-Verdugo and S. V. Luis, Chem.-Eur. J., 2010, 16, 1246; (c) J. Rubio, I. Alfonso, M. I. Burguete and S. V. Luis, Soft Matter, 2011, 7, 10737; (d) J. Rubio, I. Alfonso, M. I. Burguete and S. V. Luis, Chem. Commun., 2012, 48, 2210; (e) J. Rubio, V. MartíCentelles, M. I. Burguete and S. V. Luis, Tetrahedron, 2013, 69, 2302.

23 (a) I. Alfonso, M. I. Burguete and S. V. Luis, J. Org. Chem., 2006, 71, 2242; (b) I. Alfonso, M. I. Burguete, F. Galindo, S. V. Luis and L. Vigara, J. Org. Chem., 2007, 72, 7947; (c) E. Faggi, S. V. Luis and I. Alfonso, RSC Adv., 2013, 3, 11556. 24 (a) S. Blasco, M. I. Burguete, M. P. Clares, E. García-España, J. Escorihuela and S. V. Luis, Inorg. Chem., 2010, 490, 7841; (b) I. Martí, A. Ferrer, J. Escorihuela, M. I. Burguete and S. V. Luis, Dalton Trans., 2012, 41, 6764.

25 (a) J. Becerril, M. Bolte, M. I. Burguete, F. Galindo, E. GarcíaEspaña, S. V. Luis and J. F. Miravet, J. Am. Chem. Soc., 2003, 125, 6677; (b) S. Blasco, M. I. Burguete, M. P. Clares, E. García-España, J. Escorihuela and S. V. Luis, Inorg. Chem., 2010, 49, 7841; (c) I. Martí, A. Ferrer, J. Escorihuela, M. I. Burguete and S. V. Luis, Dalton Trans., 2012, 6764.

26 P. D. Wadhavane, M. A. Izquierdo, D. Lutters, M. I. Burguete, M. J. Marin, D. A. Russell, F. Galindo and S. V. Luis, Org. Biomol. Chem., 2014, 12, 823.

27 P. Paoletti, Pure Appl. Chem., 1984, 56, 491.

28 (a) B. Altava, M. I. Burguete, S. V. Luis, J. F. Miravet, E. García-España, V. Marcelino and C. Soriano, Tetrahedron, 1997, 53, 4751; (b) S. Andrés, B. Escuder, A. Domènech, E. García-España, S. V. Luis, V. Marcelino, J. M. Llinares, J. A. Ramírez and C. Soriano, J. Phys. Org. Chem., 2001, 14, 495.
29 (a) F. Rosu, E. de Pauw and V. Gabelica, Biochimie, 2008, 90, 1074; (b) E. B. Erba, K. Barylyuk, Y. Yang and R. Zenobi, Anal. Chem., 2011, 83, 9251; (c) L. Cera and C. A. Schalley, Chem. Soc. Rev., 2014, 43, 1800.

30 (a) K. Schug, P. Fryčák, N. M. Maier and W. Lindner, Anal. Chem., 2005, 77, 3660; (b) A. Di Tullio, S. Reale and F. J. De Angelis, Mass Spectrom., 2005, 40, 845; (c) T. Becherer, D. Meshcheryakov, A. Springer, V. Böhmerb and C. A. Schalley, J. Mass Spectrom., 2009, 44, 1338; (d) W. Jiang, A. Schäfer, P. C. Mohr and C. A. Schalley, J. Am. Chem. Soc., 2010, 132, 2309; (e) V. Lemaur, G. Carroy, F. Poussigue, F. Chirot, J. de Winter, L. Isaacs, P. Dugourd, J. Cornil and P. Gerbaux, ChemPlusChem, 2013, 78, 959; $(f)$ D. Cubrilovic, W. Haap, K. Barylyuk, A. Ruf, M. Badertscher, M. Gubler, T. Tetaz, C. Joseph, J. Benz and R. Zenobi, ACS Chem. Biol., 2014, 9, 218.

31 (a) T. R. Wagler, Y. Fang and C. J. Burrows, J. Org. Chem., 1989, 54, 1584; (b) B. Dangel, M. Clarke, J. Haley, D. Sames and R. Polt, J. Am. Chem. Soc., 1997, 119, 10865; (c) C. L. Weeks, P. Turner, R. R. Fenton and P. A. Lay, J. Chem. Soc., Dalton Trans., 2002, 931; (d) M. I. Burguete, F. Galindo, S. V. Luis and L. Vigara, Dalton Trans., 2007, 4027; (e) J. Singh, G. Hundal and R. Gupta, Eur. J. Inorg. Chem., 2008, 2052; (f) R. Shakya, A. Jozwiuk, D. R. Powell and R. P. Houser, Inorg. Chem., 2009, 48, 4083.

32 (a) R. Polt, B. D. Kelly, B. D. Dangel, U. B. Tadikonda, R. E. Ross, A. M. Raitsimring and A. V. Astashkin, Inorg. Chem., 2003, 42, 566; (b) S. Autzen, H.-G. Korth, R. Boese, H. de Groot and R. Sustmann, Eur. J. Inorg. Chem., 2003, 1401.

33 G. A. McLachlan, G. D. Fallon, R. L. Martin and L. Spiccia, Inorg. Chem., 1995, 34, 254.

34 E. C. Constable, C. E. Housecroft, J. R. Price and J. A. Zampese, CrystEngComm, 2010, 12, 3163.

35 E. García-España and S. V. Luis, Supramol. Chem., 1996, 6, 257.

36 (a) E. García-España, M.-J. Ballester, F. Lloret, J. M. Moratal, J. Faus and A. Bianchi, J. Chem. Soc., Dalton Trans., 1988, 101; (b) M. I. Burguete, E. García-España, L. López-Diago, S. V. Luis, J. F. Miravet and D. Sroczynski, Org. Biomol. Chem., 2007, 5, 1935.

37 P. Gans, A. Sabatini and A. Vacca, Talanta, 1996, 43, 1739. 38 L. Alderighi, P. Gans, A. Ienco, D. Peters and A. Vacca, Coord. Chem. Rev., 1999, 184, 311.

39 (a) P. K. Glasoe and F. A. Long, J. Phys. Chem., 1960, 64, 188; (b) A. K. Covington, M. Paabo, R. A. Robinson and R. G. Bates, Anal. Chem., 1968, 40, 700.

40 (a) MassLynx Software, version 4.0; (b) S. Moco, R. J. Bino, O. Vorst, H. a. Verhoeven, J. de Groot, T. A. van Beek, J. Vervoot and R. C. H. de Vos, Plant Physiolgy, 2006, 41, 1205. 